\title{
Effect of Sulfur Content in the Crude Oil to the Corrosion Behaviour of Internal Surface of API 5L X65 Petroleum Pipeline Steel
}

\author{
Mohd Asyadi Azam (0000-0001-8551-7559), Nur Ezyanie Safie (0000-0003-4360-785X), Hazwan Hasif Hamdan \\ Fakulti Kejuruteraan Pembuatan, Universiti Teknikal Malaysia Melaka, Hang Tuah Jaya, 76100 Durian Tunggal, \\ Melaka, Malaysia. E-mail: asyadi@utem.edu.my
}

This work discussed the corrosion behaviour of the internal surface of pipeline steel caused by petroleum products' composition, particularly crude oil. Internal and external pipeline corrosion is the notable cause of pipeline failure in Malaysia's oil and gas industry. However, internal corrosion is preferred to be concerned in this work because it involved one of the significant corrosive media in crude oil, such as sulfur content. This project aims to find the sulfur concentration in the crude oil using Fourier transform infrared spectroscopy and atomic absorption spectroscopy. The corrosion rate, corrosion current and corrosion potential of the API 5L X65 grade carbon steel pipeline in different simulated $\mathrm{H}_{2} \mathrm{SO}_{4}$ solution concentrations were carried out using the Tafel extrapolation technique. The samples' corrosion properties were morphologically measured through the optical microscope, scanning electron microscope, and energy dispersive $\mathrm{X}$-ray analyses. The results showed pipeline steel's corrosion rate significantly increased with increasing $\mathrm{H}_{2} \mathrm{SO}_{4}$ concentrations. The corrosion products formed on the pipeline steel surfaces were mainly composed of iron sulphate, iron sulphide, and iron oxide. These findings are crucial to understanding the corrosion behaviour caused by crude oil and should be further investigated with the other influential factors such as temperature and petroleum flowing velocity.

Keywords: API 5L X65 pipeline steel, crude oil, corrosion behaviour, $\mathrm{H}_{2} \mathrm{SO}_{4}$ concentration, Tafel extrapolation

\section{Introduction}

Corrosion is the leading failure cause for the pipelines in the world. Most of the pipeline failures were because of the internal corrosion, which was more frequent than external corrosion [1-4]. In the oil and gas industry, a large amount of crude oil usually needs adequate transportation, and the pipeline is the best solution. However, any failure regarding the crude oil pipelines' safety and continuous operation may affect the economic, environmental, and life-safety implications.

This project's focus is to study crude oil compositions such as sulfur, which may significantly affect the petroleum pipeline's corrosion properties [5-7]. This information is necessary to predict the corrosion mechanism where crude oil flows in the pipeline. This study is critical because the corrosion caused by crude oil is less investigated than the corrosion caused by gases in the pipeline. Previous works are mainly focused on the corrosion in the pipeline caused by natural gases rather than the crude oil [8-11]. Internal corrosion costs more than compared to the external corrosion. This is because of the mitigation that cannot be easily maintained and inspected $[12,13]$. The corrosion of internal pipeline surface is usually caused by the gas and the most popular corrosion is carbon dioxide $\left(\mathrm{CO}_{2}\right)$ and hydrogen sulfide $\left(\mathrm{H}_{2} \mathrm{~S}\right)$ corrosions $[14,15]$.
Therefore, this study was carried out to justify the corrosion caused by crude oil content. The analysis of crude oil composition related to the corrosion properties is critical in corrosion behaviour. Understanding the crude oil composition and corrosion mechanism is an excellent method to predict the corrosion properties of the pipeline surfaces $[16,17]$.

In this paper, the effect of the sulfur content in the crude oil on the API 5L X65 pipeline's corrosion behaviour has been explored. The corrosion product's morphology and corroded pipeline samples' corrosion rates were also discussed. This project aims to study the corrosion behaviour of the API 5L X65 pipeline's internal surface. Thus, the objectives determine the sulfur concentration in the crude oil, conducting the electrochemical measurement to determine the corrosion rate and explaining the morphological analysis of the corroded pipeline.

\section{Materials and methods}

2.1 Elemental analysis of sulfur content in the crude oil

The sulfur-related functional groups were analysed using Fourier-transform infrared spectroscopy (FTIR; Perkin Elmer 1000) with attenuated total reflection (ATR) technique. Also, the atomic absorption spectroscopy (AAS) analysis was done to confirm the sulfur concentration in the crude oil, and the testing 
results were taken three times to get the average concentration of sulfur in the crude oil.

\subsection{Specimen preparation}

API 5L X65 pipeline carbon steel the working electrode and the elemental compositions are shown in Table 1. The specimen was connected to copper wire and covered with epoxy resin with an exposed surface area of $1.0 \mathrm{~cm}^{2}$. After the cold mounting process, the specimens were ground with the 200, 400, $600,800,1500,2400$, and 2500 grit of silicon carbide paper and then the specimens were washed with distilled water.

Tab. 1 Elementals' composition of API 5L X65 pipeline steel. (Source: https://wmw.api5lx.com/api5lx-grades/)

\begin{tabular}{|c|c|}
\hline Element & Composition (wt. \%) \\
\hline Carbon (C) & 0.16 \\
\hline Silicon (Si) & 0.45 \\
\hline Manganese (Mn) & 1.65 \\
\hline Phosphorous (P) & 0.02 \\
\hline Sulfur (S) & 0.01 \\
\hline Vanadium (V) & 0.09 \\
\hline Niobium (Nb) & 0.05 \\
\hline Titanium (Ti) & 0.06 \\
\hline
\end{tabular}

\subsection{Experimental setup for corrosion testing}

For the corrosion test, databases such as specimen density, specimen exposed area, scan rate, and equivalent weight are referring to the American Society for Testing and Materials (ASTM) G102 standard which is a standard practice for calculation of corrosion rates and related information from electrochemical measurements. Experiments were conducted at atmospheric pressure in a glass cell. A typical threeelectrode cell configuration was used in which used $\mathrm{Ag} / \mathrm{AgCl}$ as the reference electrode, a graphite rod as the counter electrode and the pipeline steel specimen as the working electrode. For the electrochemical tests, the $\mathrm{H}_{2} \mathrm{SO}_{4}$ solutions with different concentrations were prepared. The $\mathrm{H}_{2} \mathrm{SO}_{4}$ solution and distilled water were used to prepare the electrolyte solutions with different concentrations using the dilution method. $1.00 \mathrm{M} \mathrm{H}_{2} \mathrm{SO}_{4}$ was used as the first concentration and was prepared without dilution. The other concentrations of $\mathrm{H}_{2} \mathrm{SO}_{4}$ were $0.75 \mathrm{M}, 0.40 \mathrm{M}, 0.20 \mathrm{M}$, and $0.05 \mathrm{M}$. The amount of distilled water used to dilute the $1.00 \mathrm{M} \mathrm{H}_{2} \mathrm{SO}_{4}$ is listed in Table 2.

The corrosion rate measurement was carried out using the Tafel extrapolation technique. The tests

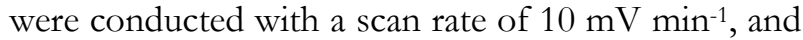
a scan range of 0.0 to $1.0 \mathrm{~V}$. This technique was used for corrosion rate measurement to compare its morphological characteristics with another concentration of $\mathrm{H}_{2} \mathrm{SO}_{4}$ in a corrosion test. These results will also be useful for evaluating corrosion properties in the pipelines used in the oil and gas industry.

Tab. 2 Concentration of solutions used as the electrolyte in the electrochemical tests.

\begin{tabular}{|c|c|c|}
\hline $\begin{array}{c}\text { Base solu- } \\
\text { tion of } \\
\mathbf{H}_{2} \mathbf{S O}_{4}(\mathbf{m L})\end{array}$ & $\begin{array}{c}\text { Amount of } \\
\text { distilled water } \\
(\mathbf{m L})\end{array}$ & $\begin{array}{c}\text { Diluted } \\
\text { concentration } \\
\mathbf{( M )}\end{array}$ \\
\hline 225 & 75 & 0.75 \\
\hline 120 & 180 & 0.40 \\
\hline 60 & 240 & 0.20 \\
\hline 15 & 285 & 0.05 \\
\hline
\end{tabular}

2.4 Surface morphology and corrosion product analyses

The specimens were analysed for the surface characterisation to study its corrosion behaviour. The morphological analysis was done using an optical microscope (OM) and scanning electron microscope (SEM). The top and cross-section images were used to analyse the corrosion products. Finally, the chemical compositions of the corrosion product produced after the corrosion test with different $\mathrm{H}_{2} \mathrm{SO}_{4}$ concentrations were studied by using energy dispersive X-ray (EDX) in parallel with the SEM analysis.

\section{Results and discussion}

3.1 Chemical compositions of the crude oil from the FTIR and AAS analyses

Figure 1 depicts the FTIR analysis of crude oil. The peak of sulfur-related functional groups has appeared between 2800 and $3000 \mathrm{~cm}^{-1}$. Spectra were got from 3800 to $800 \mathrm{~cm}^{-1}$, and the peak positions and the areas were determined using the available software package.

The areas under the absorption bands of interest were used to evaluate quantitative estimates of sulfur related functional group concentration via Beer's Law and are shown in Equation (1):

$$
A=c L_{\varepsilon}
$$

Where:
A...Absorbance [a.u.]
C...Concentration $[\mathrm{mol} / \mathrm{L}]$
L...Cell path length $[\mathrm{cm}]$
E...Molar extinction coefficient $\left[25,320 \mathrm{M}^{-1} \mathrm{~cm}^{-1}\right]$ $[18,19]$. 


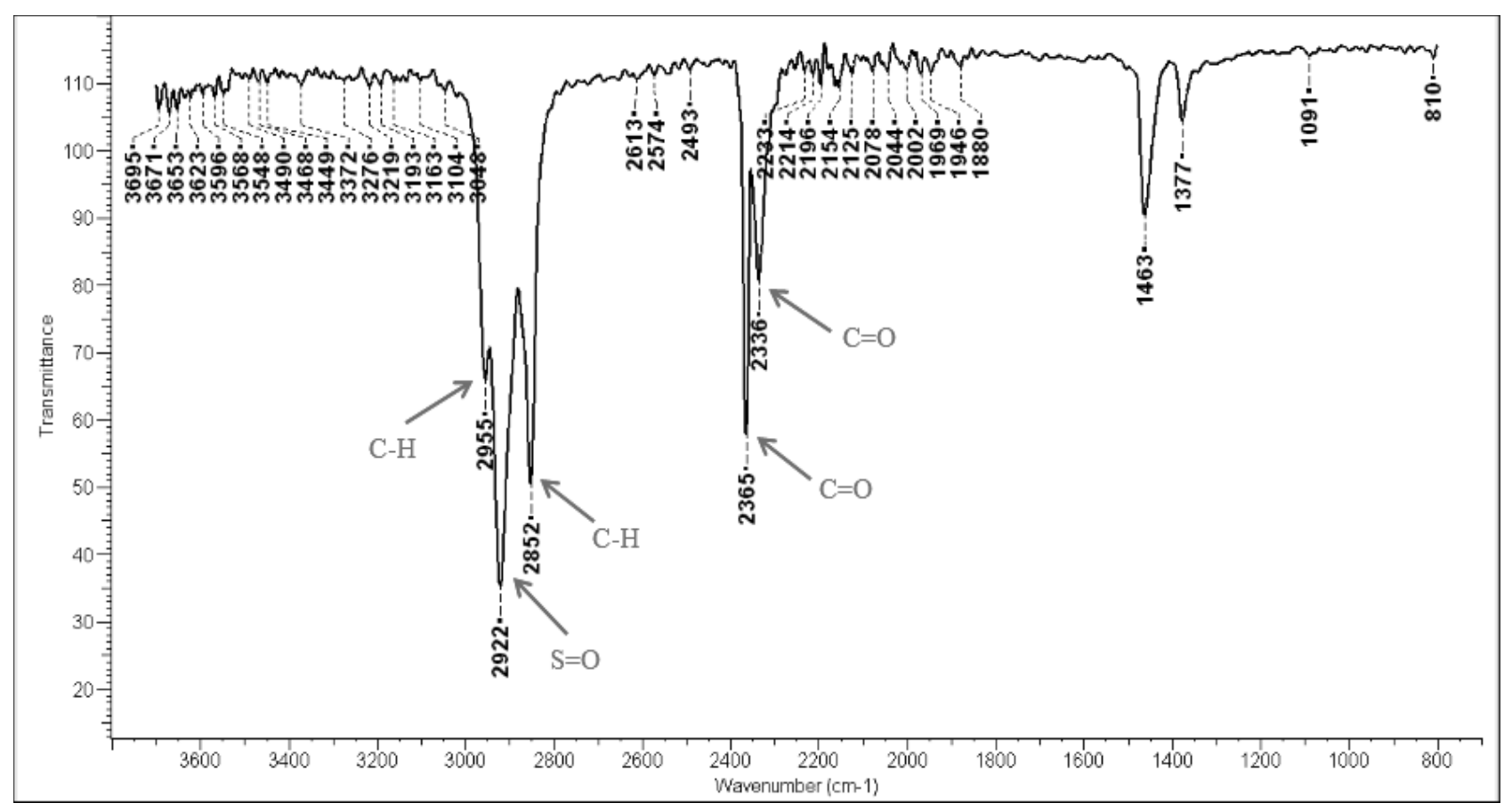

Fig. 1 FTIR analysis result of crude oil sample.

The obtained results were used as the simulated $\mathrm{H}_{2} \mathrm{SO}_{4}$ acidic solution's simulated concentration from the sulfur's calculated molarity. The $\mathrm{S}=\mathrm{O}$ spectrum was converted into the absorbance unit by Equation (2) to obtain the concentration, c from Beer's Law in Equation (1).

$$
A=2-\log 10(\% T)
$$

Where:

$\%$ T...S $=\mathrm{O}$ from FTIR spectra of crude oil [0.36\%] $A=2-\log 10(0.36)=2.44$

From Beer's Law in Equation (1),

$$
\begin{aligned}
& A=c L_{\varepsilon} \\
& 2.44=(c)(0.0001)(25320) \\
& c=0.96 M ;
\end{aligned}
$$

$\mathrm{c}$ is approximately $1.00 \mathrm{M}$.

From this analysis, significantly, the concentration of the sulfur was approximated to be $1.00 \mathrm{M}$. Therefore, it was decided that the first concentration for the acidic solution of $\mathrm{H}_{2} \mathrm{SO}_{4}$ to simulate the concentration of $\mathrm{SO}_{4}{ }^{2-}$ in crude oil was $1.00 \mathrm{M}$. Table 3 shows the concentrations and absorbance of sulfur in the crude oil sample. The concentration of sulfur will determine the concentration of $\mathrm{H}_{2} \mathrm{SO}_{4}$ as it is used as the simulated acidic solution in the corrosion test. Sulfuric acid is a colourless oily liquid and corrosive to metals. Long-term exposure to low concentrations or shortterm exposure to high concentrations can cause adverse health effects from inhalation. It is used to make fertilisers and other chemicals, in petroleum refining, iron and steel productions, and many other uses. Sulfuric acid is a sulfur oxoacid that comprises two oxo (organic compounds that contain the carbonyl group, $\mathrm{C}=\mathrm{O}$ ) and two hydroxyl (comprises one hydrogen and one oxygen atom, $\mathrm{OH}$ ) groups joined covalently to a central sulfur atom $[20,21]$. It has a role as a catalyst, and it is the conjugate acid of hydrogen sulfate. Notably, one may consider the simulated $\mathrm{H}_{2} \mathrm{SO}_{4}$ solution as the representative of the sulfur element.

Tab. $3 A A S$ analysis results for sulfur concentration in crude oil.

\begin{tabular}{|c|c|}
\hline Sample & $\begin{array}{c}\text { Concentration } \\
\text { (gS/gal) }\end{array}$ \\
\hline 1st run & 3.7350 \\
\hline 2nd run & 3.7230 \\
\hline 3rd run & 3.7120 \\
\hline
\end{tabular}

The calculation to convert $\mathrm{gS} / \mathrm{gal}$ to $\mathrm{ppm}$ unit is shown below.

$$
\begin{aligned}
& 3.7120 \mathrm{gS} / \mathrm{gal} \rightarrow \ldots \text { ppm } \\
& (3.712 \mathrm{gS}) / 1 \mathrm{gal} \times 1 \mathrm{gal} / 0.0037854 \mathrm{~m}^{3}=980 \mathrm{ppm}(\sim 1000 \mathrm{ppm})
\end{aligned}
$$

Hence,

$1000 \mathrm{ppm}=1.00 \mathrm{M}$ 
3.2 Tafel extrapolation analysis for the corrosion rate determination

The corrosion rates of pipeline steel after Tafel extrapolation analysis with different concentrations are shown in Figures 2 to 6 , and the results are summarised in Table 4. The corrosion behaviour for API 5L X65 pipeline steels was examined by the corrosion test with different concentrations of the simulated $\mathrm{H}_{2} \mathrm{SO}_{4}$ acidic solution. $\mathrm{H}_{2} \mathrm{SO}_{4}$ is the simulated solution or electrolyte representing the sulfate ion $\left(\mathrm{SO}_{4}^{2-}\right)$ in the crude oil sample. Therefore, in ppm, the concentration of $\mathrm{SO}_{4}^{2-}$ is showed to the $\mathrm{H}_{2} \mathrm{SO}_{4}$ concentration in molarity for the corrosion test.

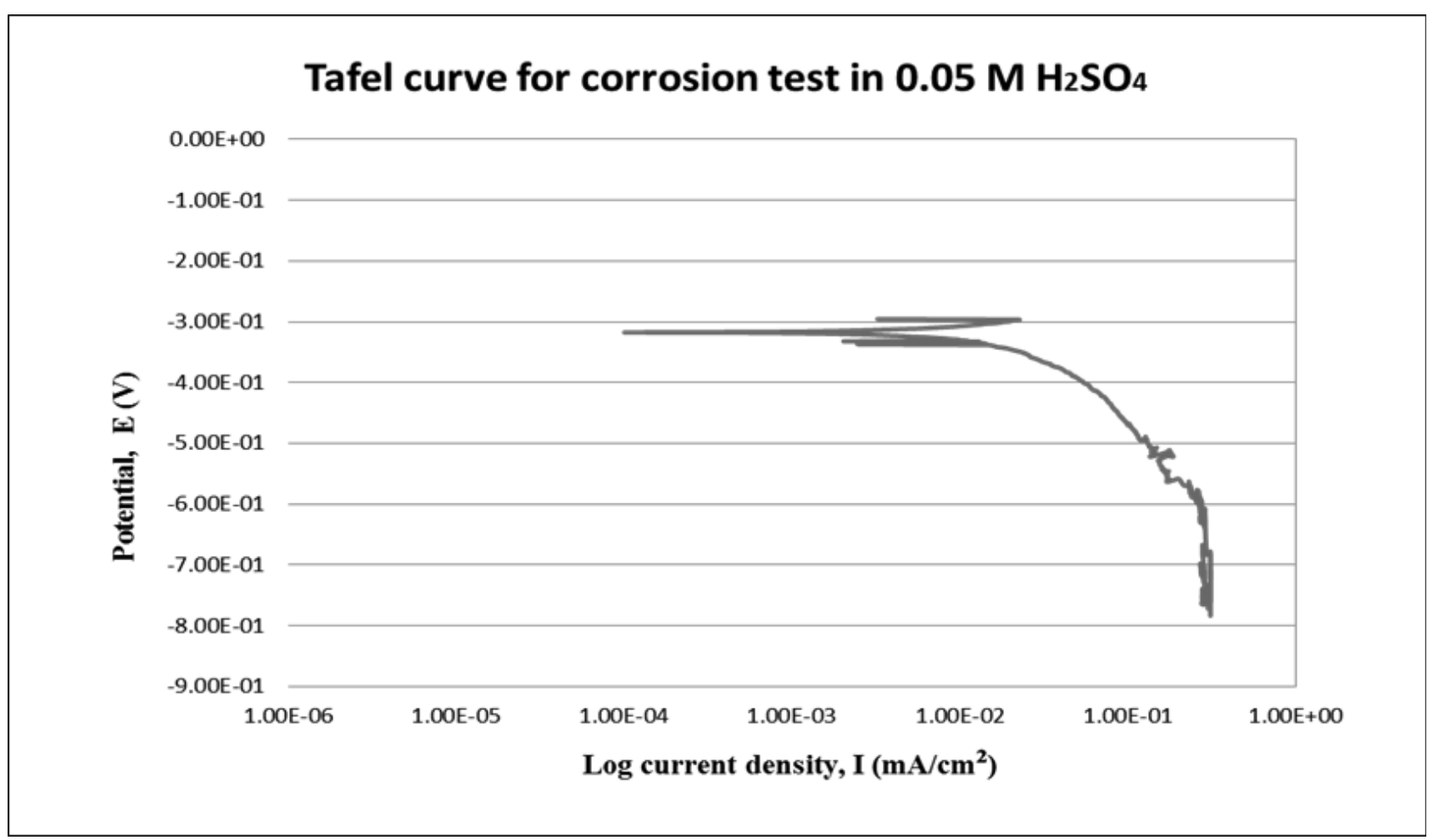

Fig. 2 Tafel curves of API $5 \mathrm{~L}$ X65 pipeline samples in $0.05 \mathrm{M} \mathrm{H}_{2} \mathrm{SO}_{4}$ concentrations

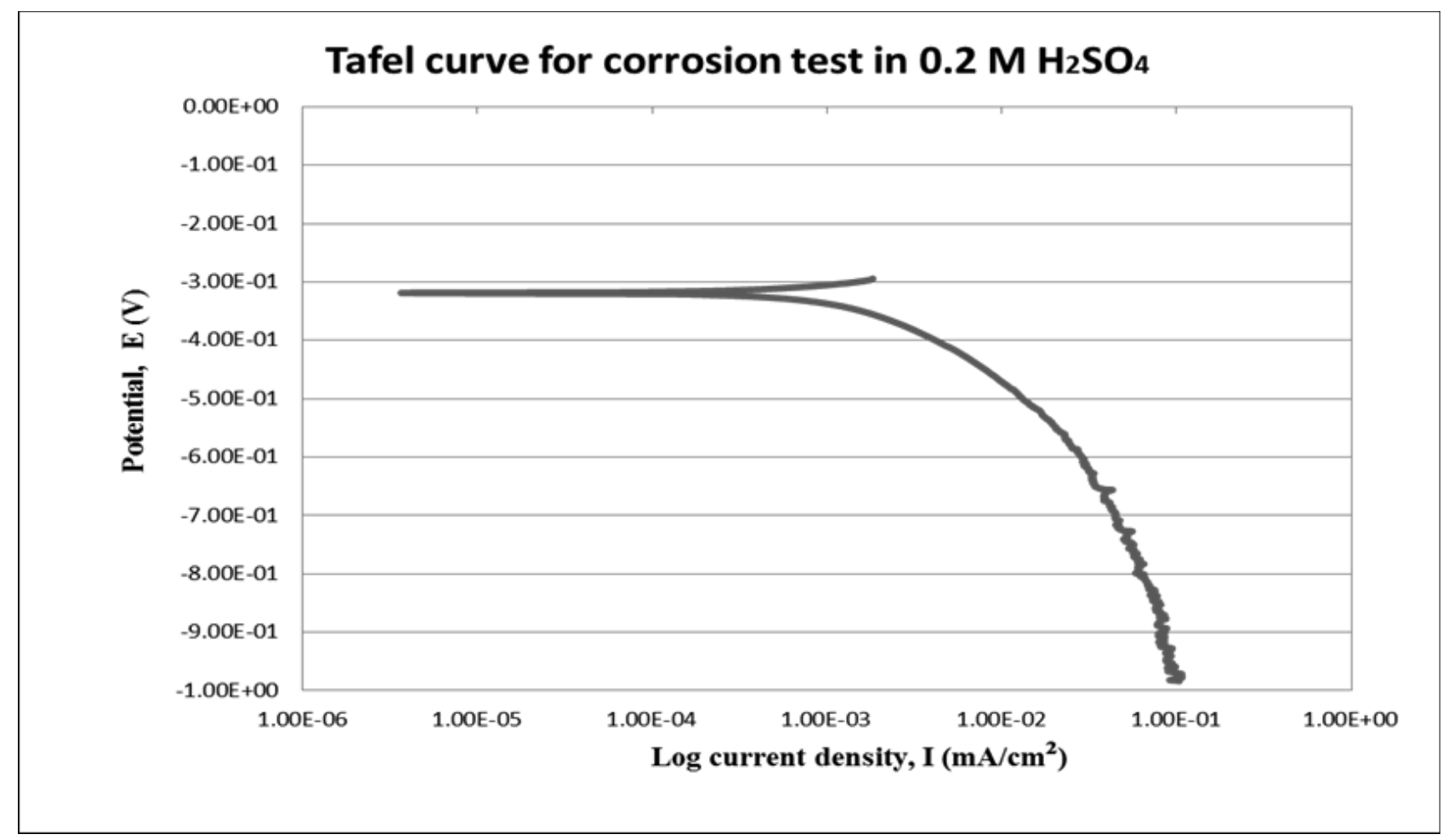

Fig. 3 Tafel curves of API $5 \mathrm{~L}$ X65 pipeline samples in $0.2 \mathrm{M} \mathrm{H}_{2} \mathrm{SO}_{4}$ concentrations. 


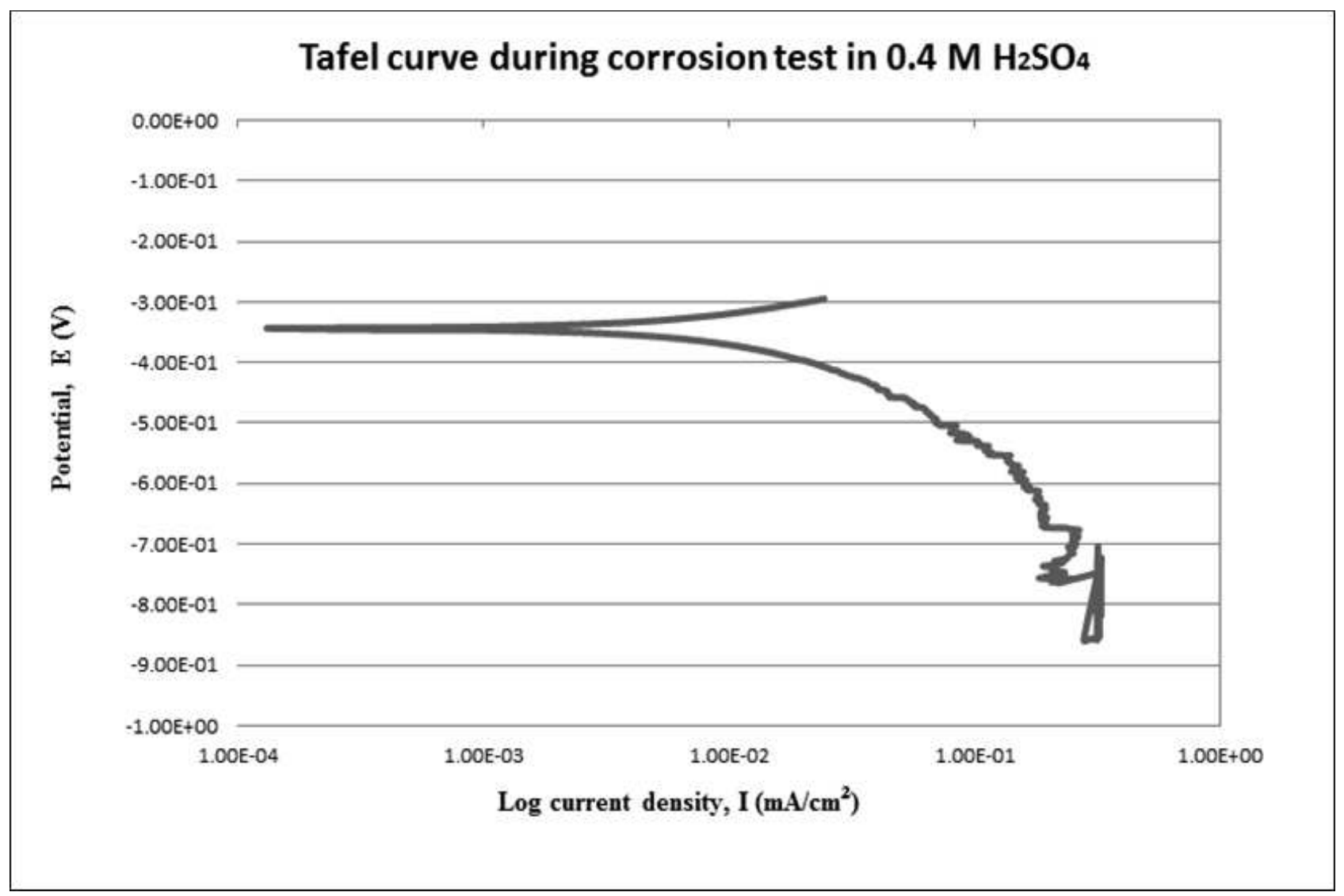

Fig. 4 Tafel curves of API $5 \mathrm{~L}$ X65 pipeline samples in $0.4 \mathrm{M} \mathrm{H}_{2} \mathrm{SO}_{4}$ concentrations.

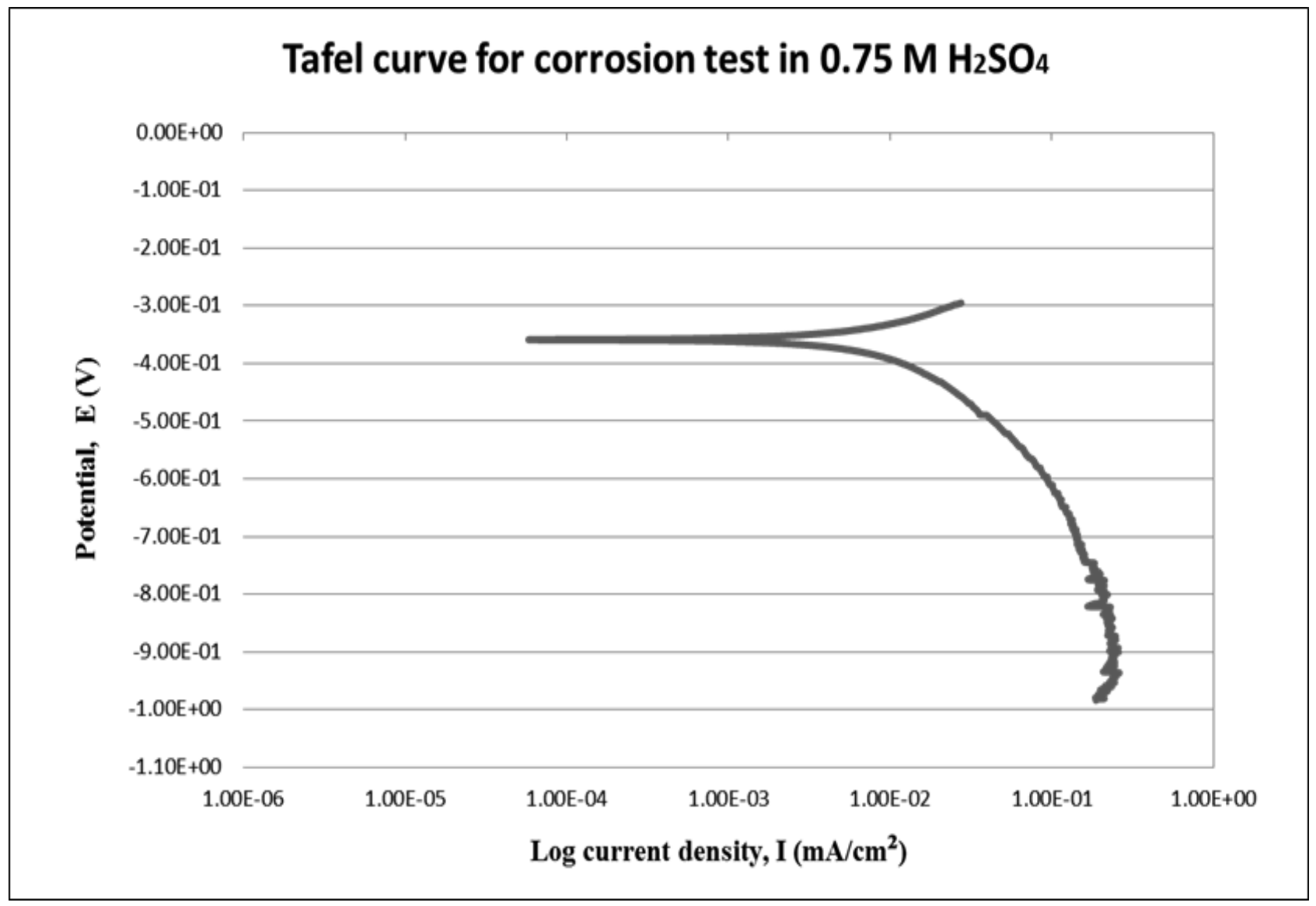

Fig. 5 Tafel curves of API $5 \mathrm{~L}$ X65 pipeline samples in $0.75 \mathrm{M} \mathrm{H}_{2} \mathrm{SO}_{4}$ concentrations. 


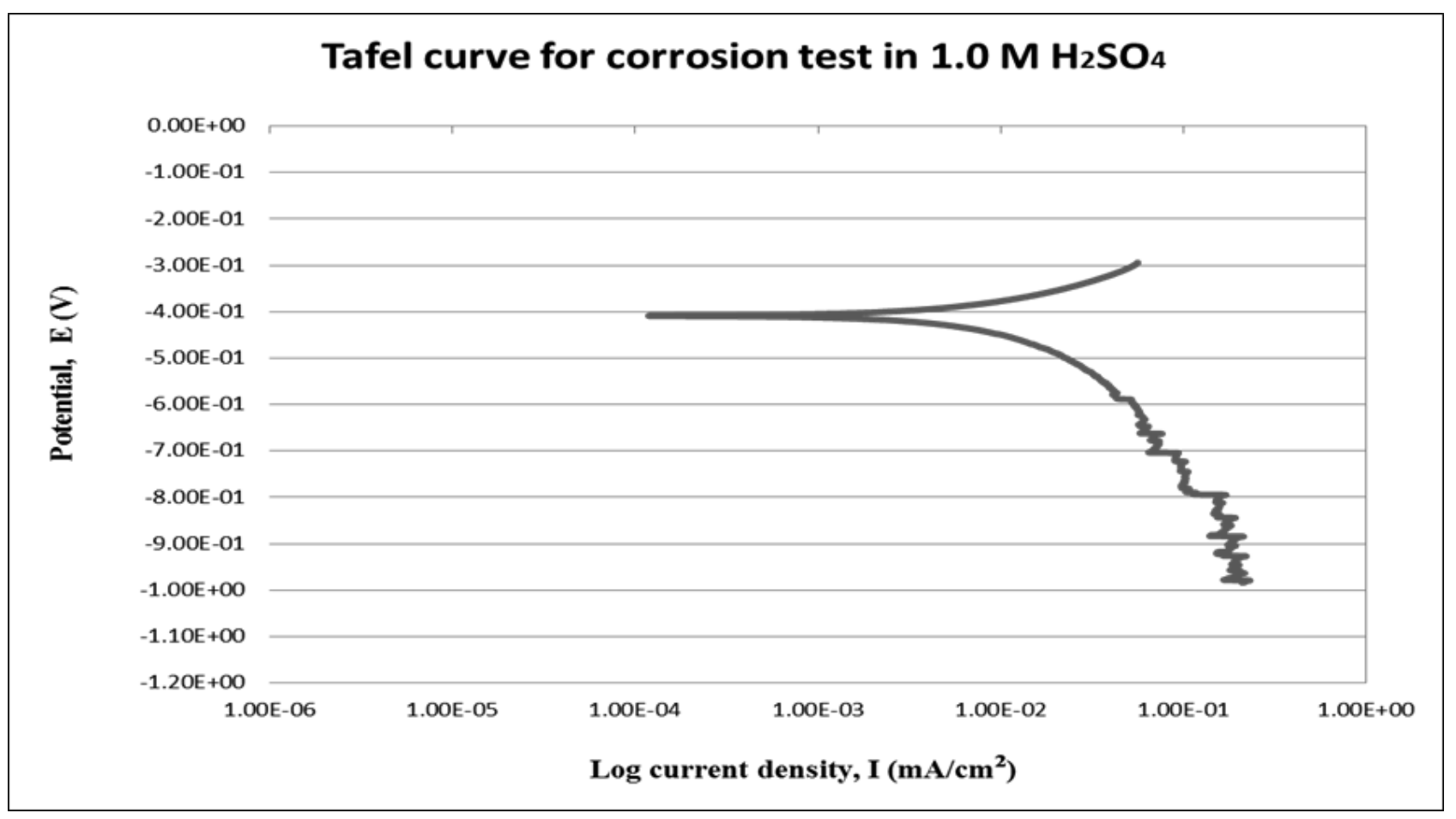

Fig. 6 Tafel curves of API $5 \mathrm{~L}$ X65 pipeline samples in $1.0 \mathrm{M} \mathrm{H}_{2} \mathrm{SO}_{4}$ concentrations.

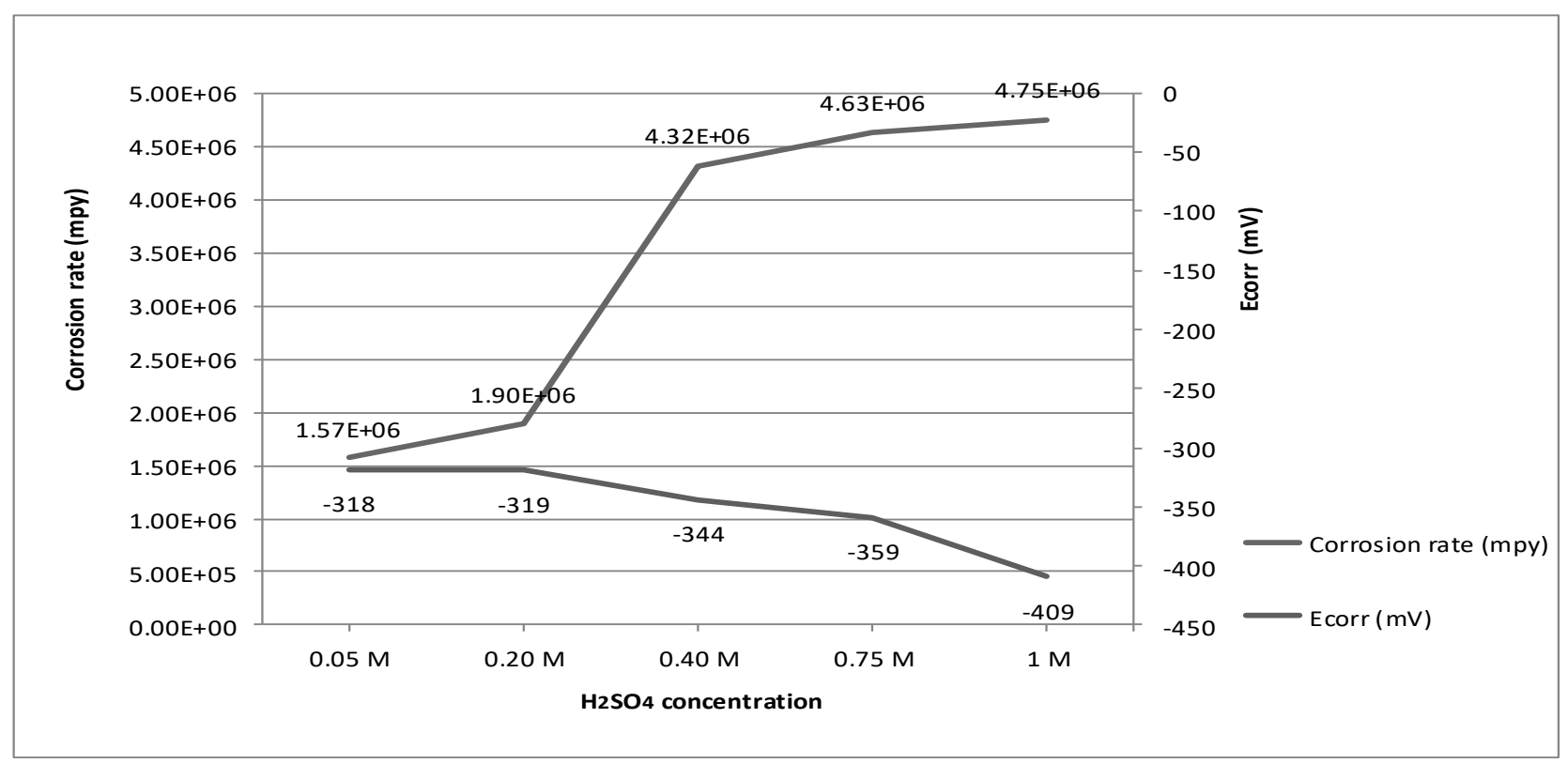

Fig. 7 Plot of corrosion rates and $\mathrm{E}_{\text {corr }}$ as a function of $\mathrm{H}_{2} \mathrm{SO}_{4}$ concentrations.

Tab. 4 The summarised results of corrosion rate, $I_{\text {corr }}$ and $E_{\text {corr }}$ at different $\mathrm{H}_{2} \mathrm{SO}_{4}$ concentrations.

\begin{tabular}{|c|c|c|c|}
\hline $\begin{array}{c}\text { Concen- } \\
\text { tration }\end{array}$ & $\begin{array}{c}\text { Corrosion } \\
\text { rate (mpy) }\end{array}$ & $\begin{array}{c}\mathbf{I}_{\text {corr }} \\
\left(\mathbf{m A} / \mathbf{c m}^{2}\right)\end{array}$ & $\begin{array}{c}\mathbf{E}_{\text {corr }} \\
\mathbf{( m V )}\end{array}$ \\
\hline $\mathbf{0 . 0 5} \mathbf{M}$ & $1.57 \times 10^{6}$ & 1.00 & -318.00 \\
\hline $\mathbf{0 . 2 0} \mathbf{M}$ & $1.90 \times 10^{6}$ & 1.06 & -319.00 \\
\hline $\mathbf{0 . 4 0} \mathbf{M}$ & $4.32 \times 10^{6}$ & 1.07 & -344.00 \\
\hline $\mathbf{0 . 7 5} \mathbf{M}$ & $4.63 \times 10^{6}$ & 3.33 & -359.00 \\
\hline $\mathbf{1 . 0 0} \mathbf{M}$ & $4.75 \times 10^{6}$ & 4.18 & -409.00 \\
\hline
\end{tabular}

It was found that the value of the corrosion rate and the corrosion current $\left(I_{\text {corr }}\right)$ is increasing with the increasing $\mathrm{H}_{2} \mathrm{SO}_{4}$ concentrations. Besides, the corrosion potential ( $\left.E_{\text {corr }}\right)$ was becoming more electrochemically negative. $E_{\text {corr }}$ values showed that when the value becomes more negative, the Tafel curve is prone to the less noble region, and the corrosion rate is increasing [22-24]. The calculated corrosion rate in the highest molarity $1.00 \mathrm{M} \mathrm{H}_{2} \mathrm{SO}_{4}$ is $4.75 \times 10^{6} \mathrm{mpy}$. The $E_{\text {corr }}$ values are becoming more active with the increasing $\mathrm{H}_{2} \mathrm{SO}_{4}$ concentrations (Figure 7), which is consistent with our previous work [25]. For example, the 
$E_{\text {corr }}$ value of $0.50 \mathrm{M} \mathrm{H}_{2} \mathrm{SO}_{4}$ is $-318.0 \mathrm{mV}$ compared to $-344.0 \mathrm{mV}$ for $0.40 \mathrm{M} \mathrm{H}_{2} \mathrm{SO}_{4}$. Besides, the corrosion rate is determined by the penetration of the oxidant (sulfuric acid) into the metal surfaces through the coating of the corrosion product, or by the dispersion of the corrosion product from the metal surface to the bulk solution. It may develop a protective layer of corrosion products. Any factor causing these measures to be accelerated would also increase corrosion risk. For carbon steel in sulfuric acid, the main factors contributing to the increase in corrosion rate are the iron sulfate $\left(\mathrm{FeSO}_{4}\right)$ solubility in the acid, the temperature and the relative movement between the metal surface and the electrolyte [26].

3.3 Microstructural analysis of the clean pipeline specimen and the morphology of the corrosion product

The microstructures of the clean internal surface of API 5L X65 pipeline carbon steel before the corrosion test is shown in Figures 8 to 10 . The phase of carbon steel mainly comprises ferrite $(\mathrm{F})$, and a mass of carbide $\left(\mathrm{Fe}_{3} \mathrm{C}\right)$ deposited in the grain boundary [27, 28]. It can be seen that there were crystal grains formed on the steel surface. The crystal grains were bulky, distributed irregularly, fine, and compact.

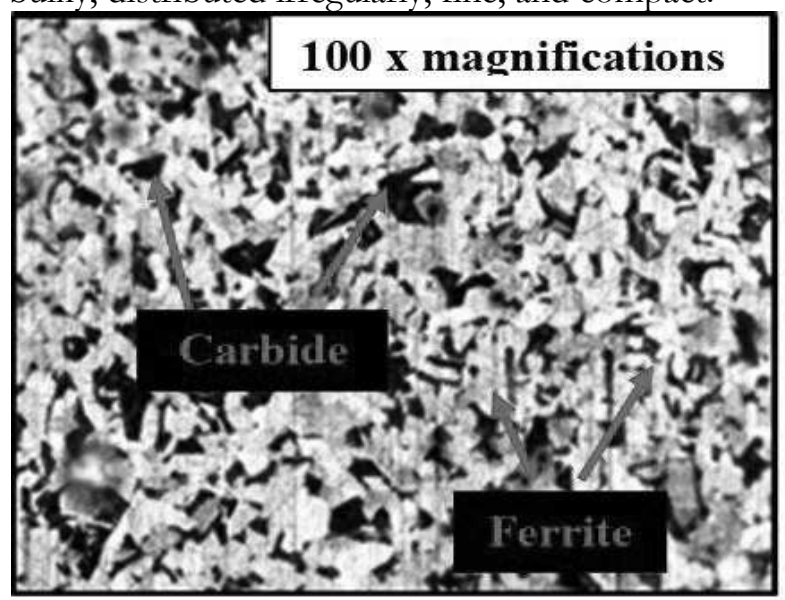

Fig. 8 The microstructures of API 5L X65 pipeline carbon steel from $O M$ (mag. 100x)

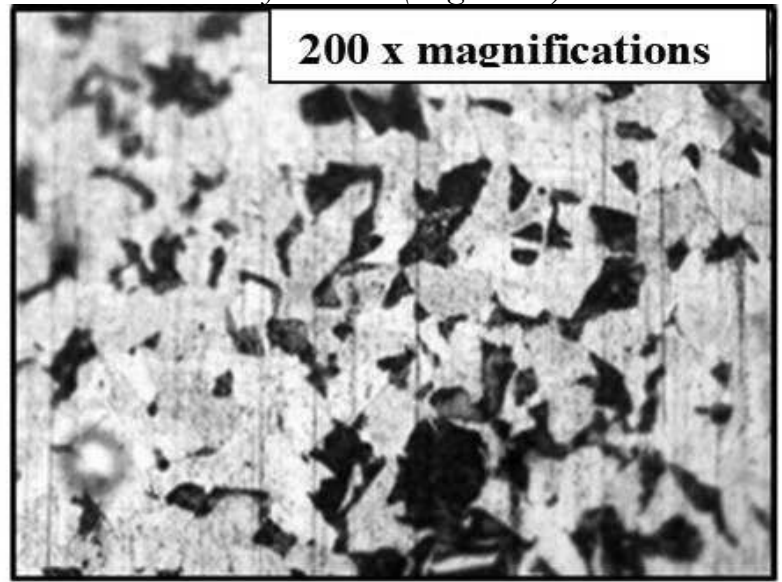

Fig. 9 The microstructures of API 5L X65 pipeline carbon steel from $O M$ (mag. 200x)

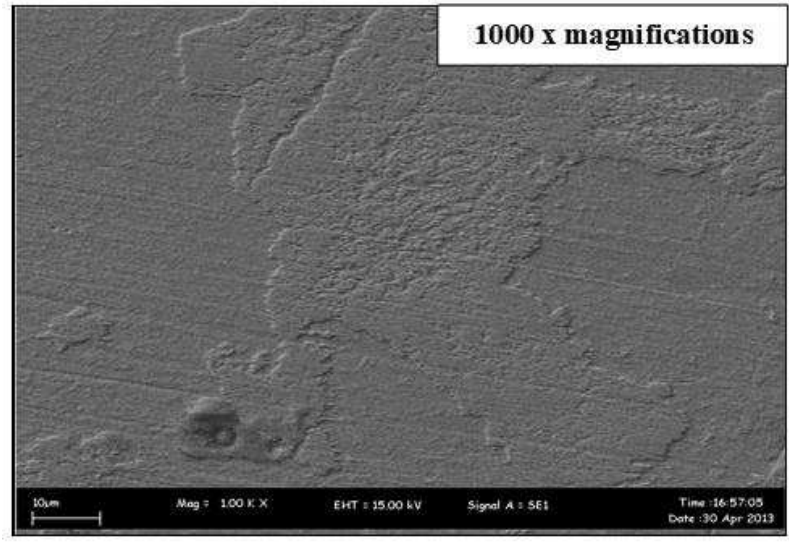

Fig. 10 The microstructures of API 5L X65 pipeline carbon steel from SEM (mag. 1000x)

Figures 11 to 20 show the SEM images of specimens in the $\mathrm{H}_{2} \mathrm{SO}_{4}$ solution with different concentrations. These images show an increasing evolution on the morphology of the corrosion films/products formed on the pipeline steel surface after the corrosion test. The average thicknesses of the corrosion product formed on the API 5L X65 pipeline surfaces are summarised in Table 5. Also, it was found that, by increasing the $\mathrm{H}_{2} \mathrm{SO}_{4}$ concentration, there was a greater pitting tendency on the pipeline steel surface (Figures 21 to 25) [29]. Pitting corrosion is a significant corrosion type and is typical for carbon steel based materials, including stainless steel [30,31]. The corrosion rate distribution reaches a relatively constant, slightly decreasing and variance after sufficiently long exposure. The quantitative distribution of the corrosion rate given in this work enables the reliable advances of cathodically protected and coated pipelines to be measured effectively [32].

Tab. 5 The average thicknesses of corrosion products formed on the surface of API 5L X65 pipeline carbon steel based on different $\mathrm{H}_{2} \mathrm{SO}_{4}$ concentrations and were captured from SEM cross-sectional images (as of Figures 16 to 20).

\begin{tabular}{|c|c|}
\hline $\begin{array}{c}\mathbf{H}_{2} \mathbf{S O}_{4} \text { concentration } \\
(\mathbf{M})\end{array}$ & $\begin{array}{c}\text { Average thickness } \\
(\boldsymbol{\mu} \mathbf{m})\end{array}$ \\
\hline 0.05 & 2.40 \\
\hline 0.20 & 2.55 \\
\hline 0.40 & 4.51 \\
\hline 0.75 & 4.66 \\
\hline 1.00 & 5.15 \\
\hline
\end{tabular}

The lifespan estimation for the pipeline is based on fluid loss during transportation into pit holes. Parameters related to corrosion, pipeline dimension and liquid flow are considered probabilistic variables. The firstorder reliability approach can estimate the likelihood of failure and the relative contribution of the various unknown parameters [33, 34]. From these analyses, 
the corrosion mechanism is related to the $\mathrm{H}_{2} \mathrm{SO}_{4}$ concentration, thereby accelerating pipeline steel corrosion rate. Other than that, the API 5L X65 steel spe- cimens dissolution in the $\mathrm{H}_{2} \mathrm{SO}_{4}$ solution could be linked to what has been proposed in the electrochemical reaction by using the Tafel extrapolation analysis.

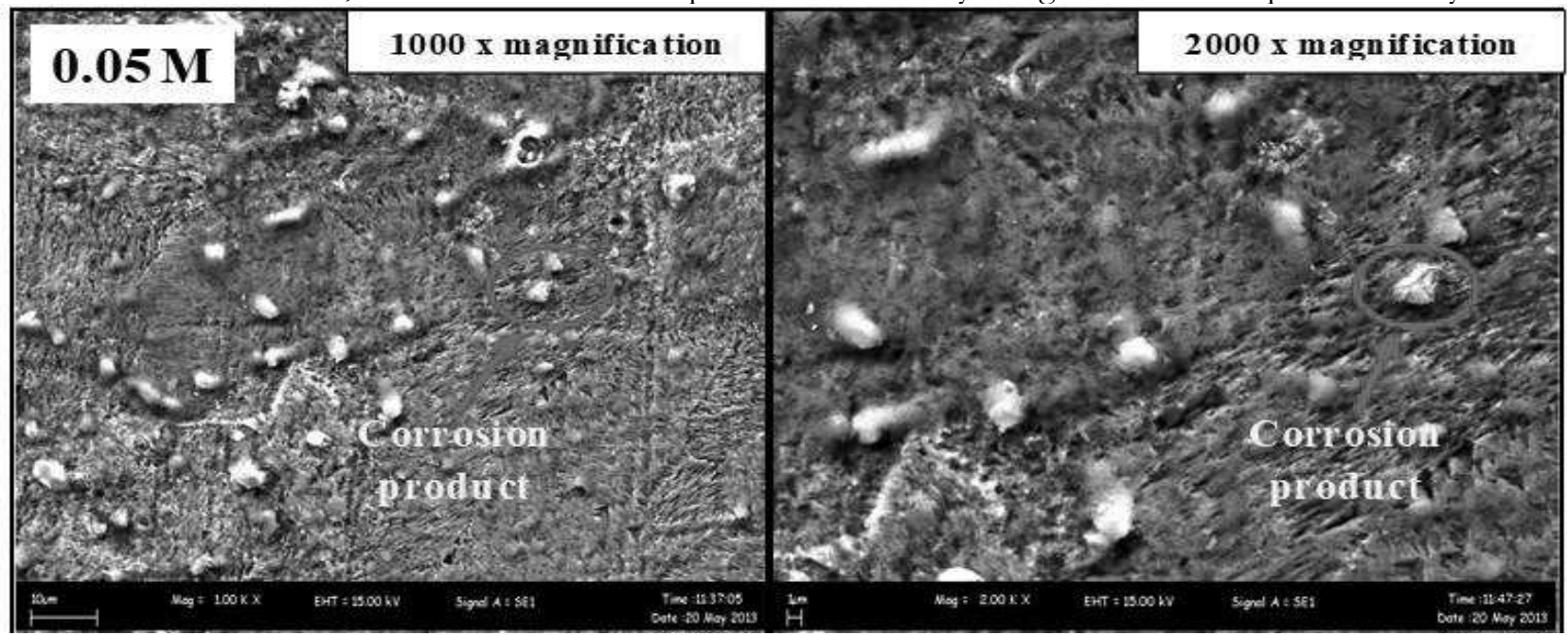

Fig. 11 Top image of SEM micrographs of the corrosion product formed on the API $5 \mathrm{~L}$ X65 pipeline samples in $0.05 \mathrm{M} \mathrm{H}_{2} \mathrm{SO}_{4}$ concentrations

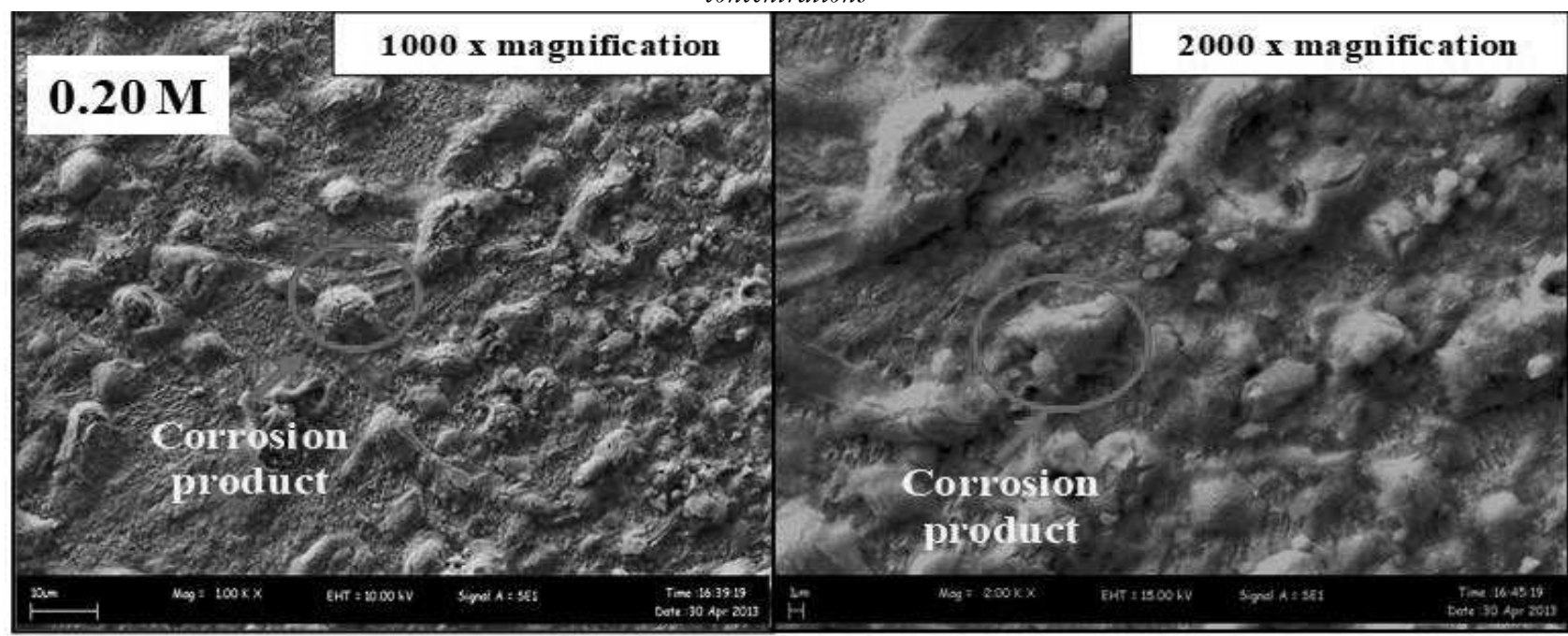

Fig. 12 Top image of SEM micrographs of the corrosion product formed on the API $5 \mathrm{~L}$ X65 pipeline samples in $0.20 \mathrm{M} \mathrm{H}_{2} \mathrm{SO}_{4}$ concentrations

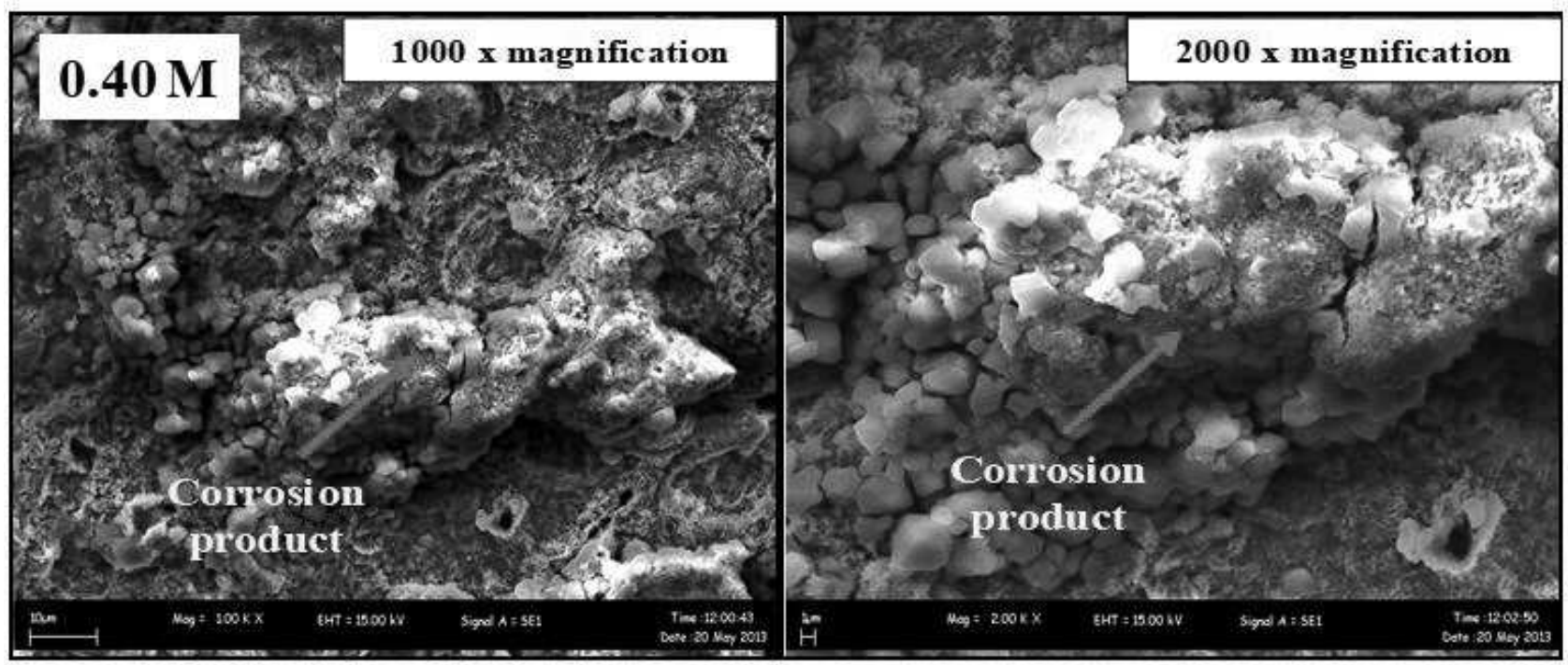

Fig. 13 Top image of SEM micrographs of the corrosion product formed on the API $5 \mathrm{~L}$ X65 pipeline samples in $0.40 \mathrm{M} \mathrm{H}_{2} \mathrm{SO}_{4}$ concentrations 


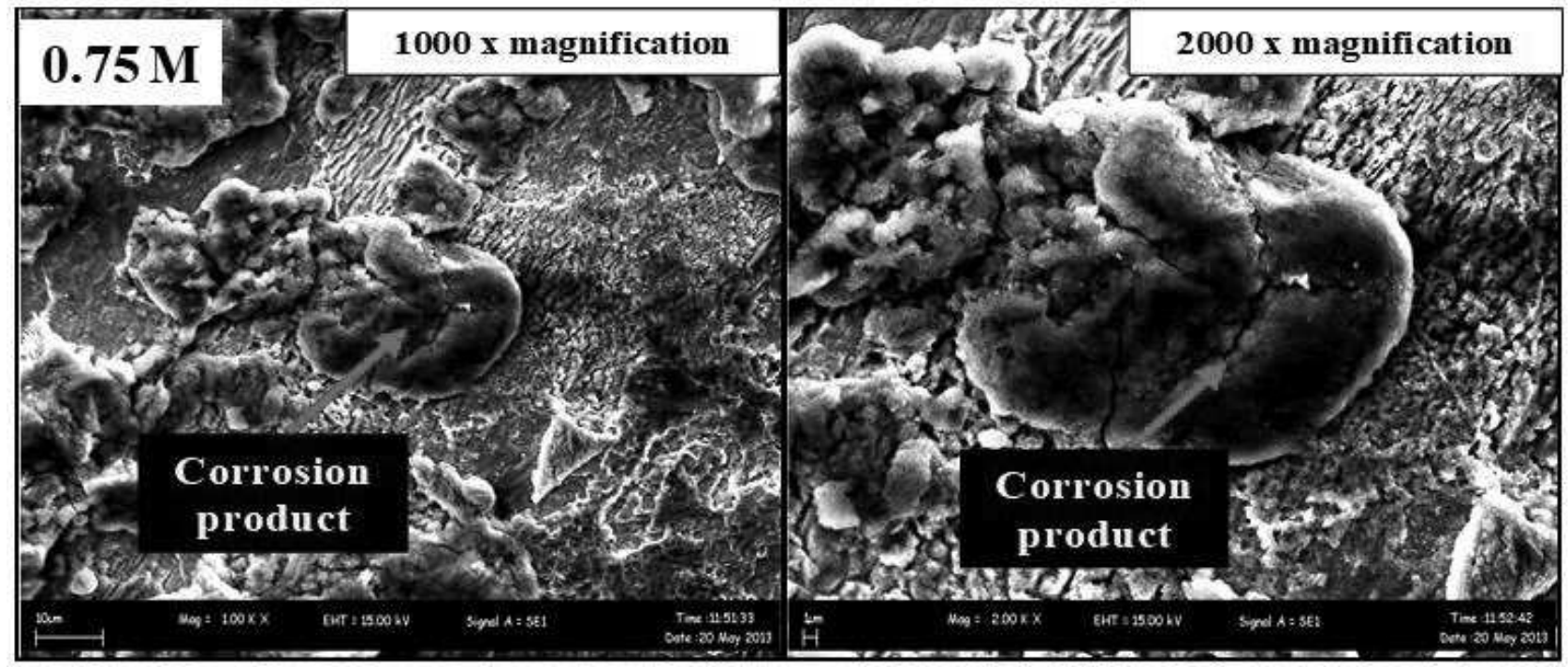

Fig. 14 Top image of SEM micrographs of the corrosion product formed on the API $5 \mathrm{~L}$ X65 pipeline samples in $0.75 \mathrm{M} \mathrm{H}_{2} \mathrm{SO}_{4}$ concentrations

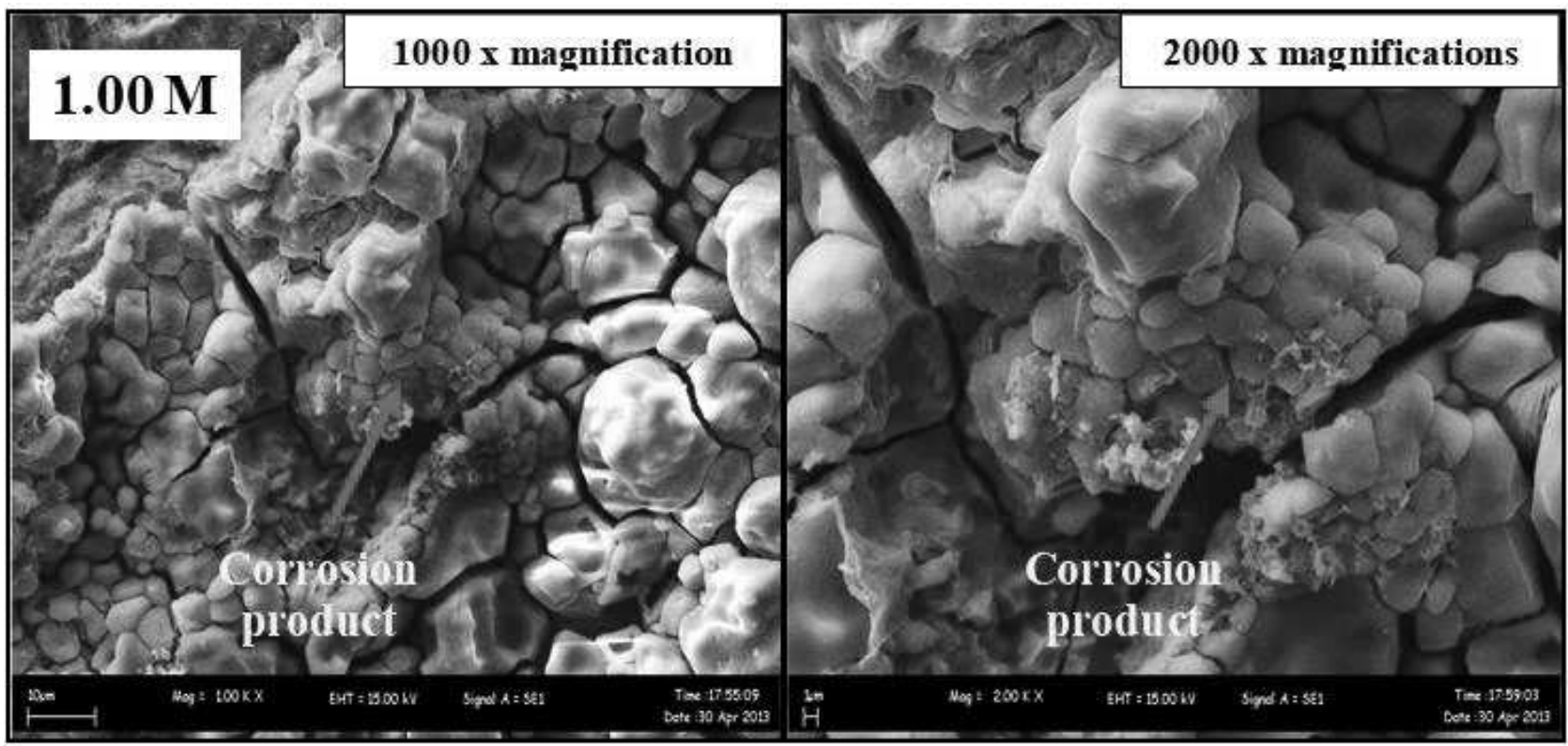

Fig. 15 Top image of SEM micrographs of the corrosion product formed on the API $5 \mathrm{~L}$ X65 pipeline samples in $1.00 \mathrm{M} \mathrm{H}_{2} \mathrm{SO}_{4}$ concentrations

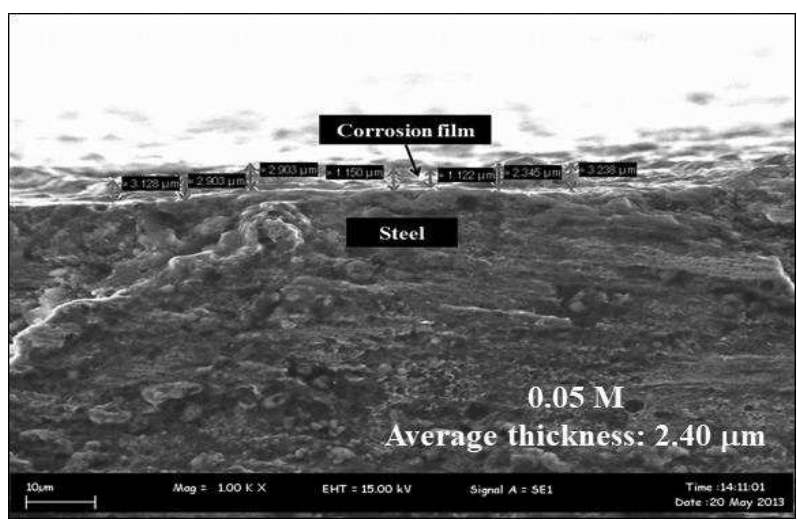

Fig. 16 Cross-sectional image of SEM micrographs of the corrosion product formed on the API 5L X65 pipeline samples in $0.05 \mathrm{M} \mathrm{H}_{2} \mathrm{SO}_{4}$ concentrations (magnification: $1000 x)$

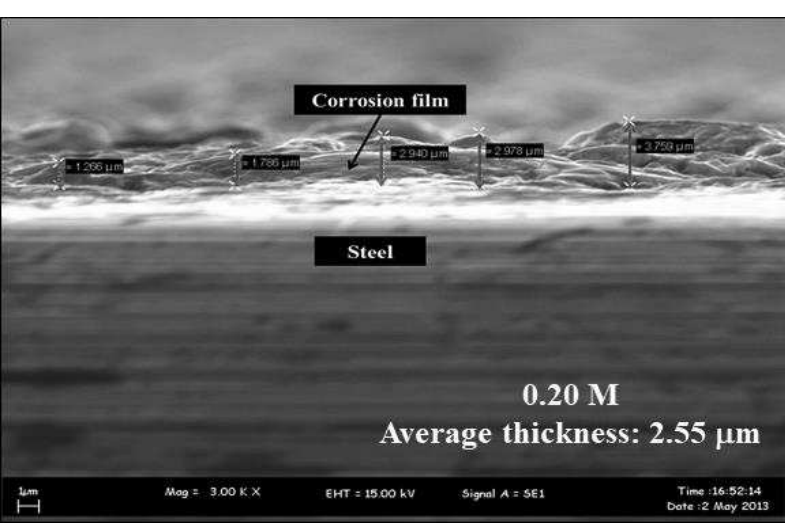

Fig. 17 Cross-sectional image of SEM micrographs of the corrosion product formed on the API 5L X65 pipeline samples in $0.20 \mathrm{M} \mathrm{H}_{2} \mathrm{SO}_{4}$ concentrations (magnification: $3000 x)$ 


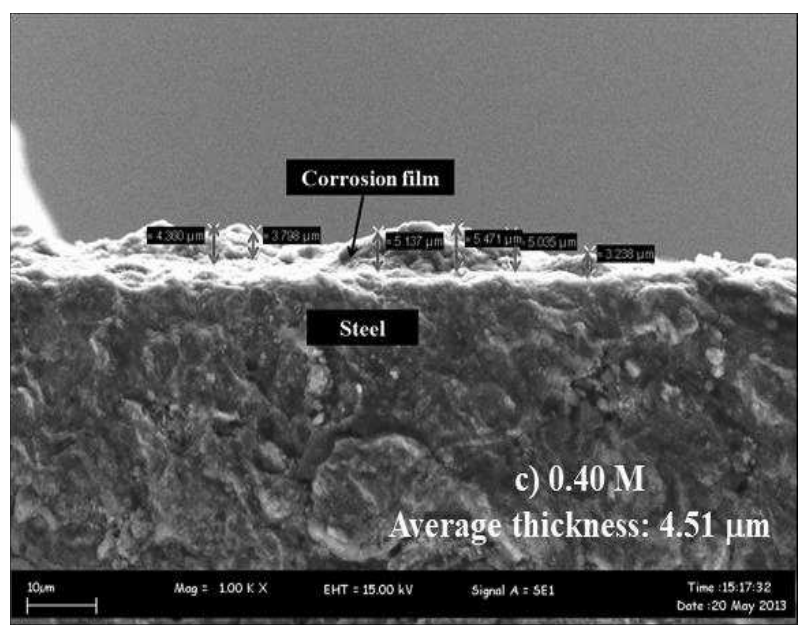

Fig. 18 Cross-sectional image of SEM micrographs of the corrosion product formed on the API 5L X65 pipeline samples in $0.40 \mathrm{M} \mathrm{H}_{2} \mathrm{SO}_{4}$ concentrations (magnification: 1000x)

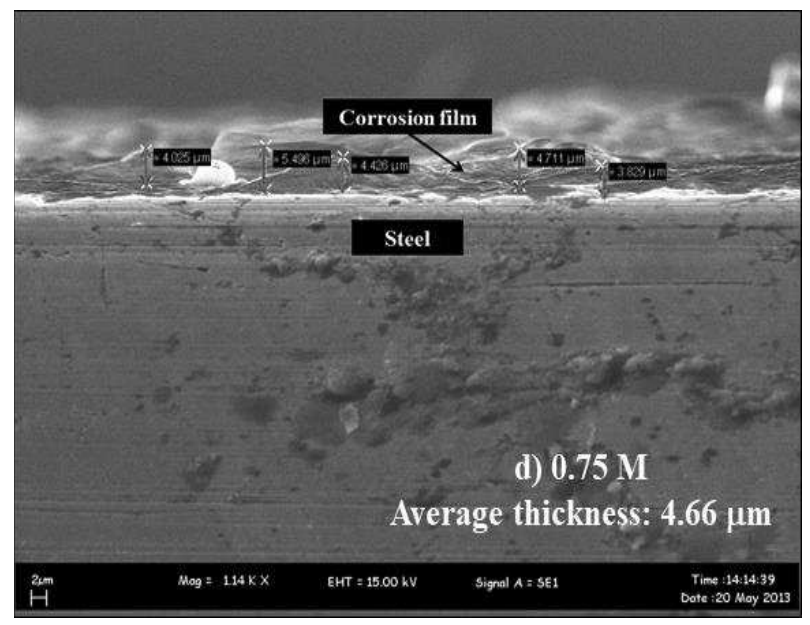

Fig. 19 Cross-sectional image of SEM micrographs of the corrosion product formed on the API 5L X65 pipeline samples in $0.75 \mathrm{M} \mathrm{H}_{2} \mathrm{SO}_{4}$ concentrations (magnification: 1140x)

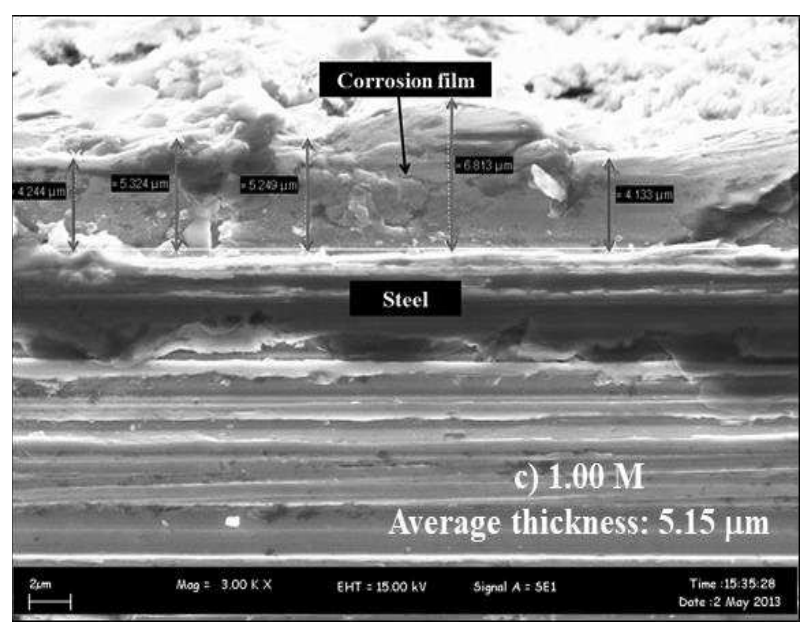

Fig. 20 Cross-sectional image of SEM micrographs of the corrosion product formed on the API 5L X65 pipeline samples in $1.00 \mathrm{M} \mathrm{H}_{2} \mathrm{SO}_{4}$ concentrations (magnification: 3000x)

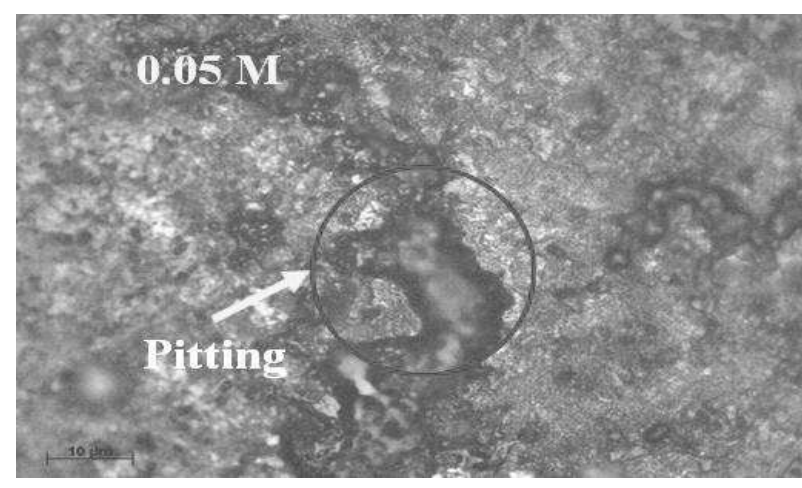

Fig. 21 Optical image of the corrosion product formed on the API 5L X65 pipeline specimens in $0.05 \mathrm{M} \mathrm{H}_{2} \mathrm{SO}_{4}$ concentrations

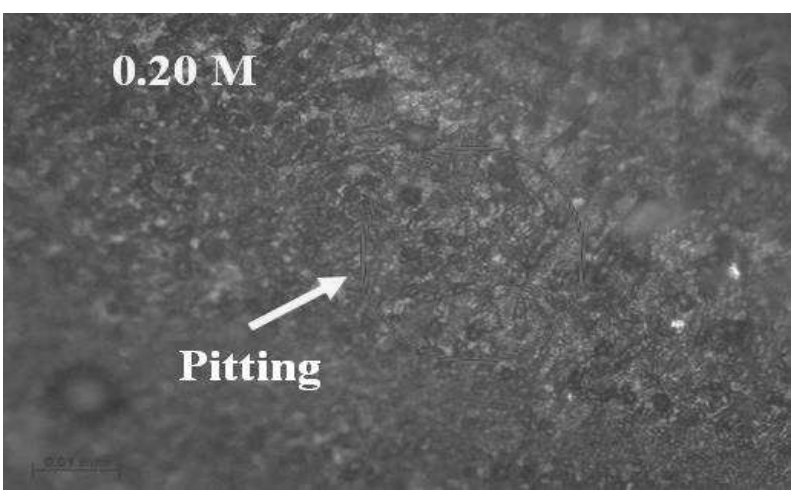

Fig. 22 Optical image of the corrosion product formed on the API $5 \mathrm{~L}$ X65 pipeline specimens in $0.20 \mathrm{M} \mathrm{H}_{2} \mathrm{SO}_{4}$ concentrations

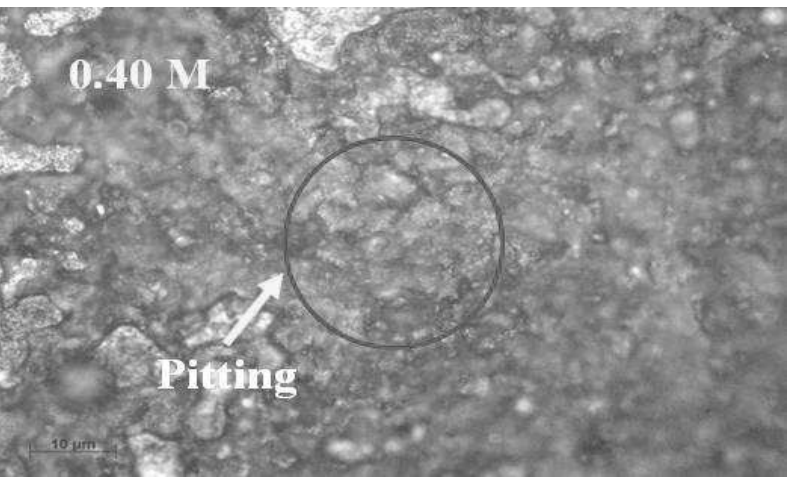

Fig. 23 Optical image of the corrosion product formed on the API $5 \mathrm{~L}$ X65 pipeline specimens in $0.40 \mathrm{M} \mathrm{H}_{2} \mathrm{SO}_{4}$ concentrations

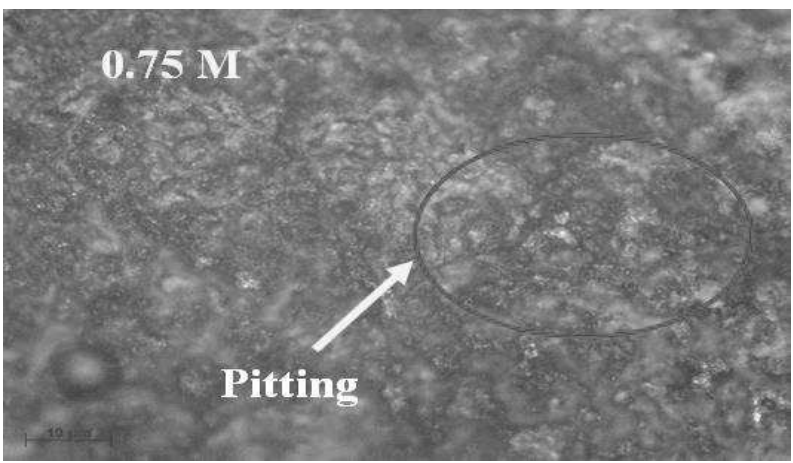

Fig. 24 Optical image of the corrosion product formed on the API 5L X65 pipeline specimens in $0.75 \mathrm{M} \mathrm{H}_{2} \mathrm{SO}_{4}$ concentrations 


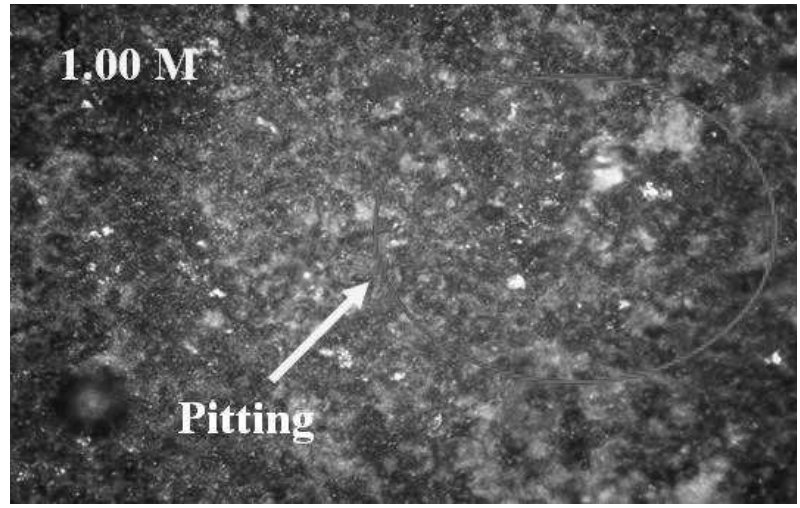

Fig. 25 Optical image of the corrosion product formed on the API 5L X65 pipeline specimens in $1.00 \mathrm{M} \mathrm{H}_{2} \mathrm{SO}_{4}$ concentrations

\subsection{Corrosion product confirmation by EDX analysis}

Figure 26 shows the SEM image, while Figures 27 to 28 show the EDX analysis and the peak of elements presented in the corrosion product after the corrosion test with $1.00 \mathrm{M} \mathrm{H}_{2} \mathrm{SO}_{4}$. The corrosion product's composition is shown in the corresponding EDX analysis and table 6. The peak of iron $(\mathrm{Fe})$, oxygen $(\mathrm{O})$, carbon (C), and sulfur (S) are among the significant elements in the corrosion products. It corresponds to the basic elemental composition of the pipeline steel. Nodular corrosion products with a sulfate-rich composition were formed [35]. Fe peaks are considerably suppressed because of Fe's dissolution in the acid solution. The electrons consumed at the cathode because of the reduction of the hydrogen ion are produced during the dissolution of the Fe alloy in the corrosive acid medium by anodic reaction [36]. Also, ferrous ion is a corrosion inhibitor, and changing liquid rates in these tanks and vessels can affect the corrosion rate in the plant or pipeline system [37].

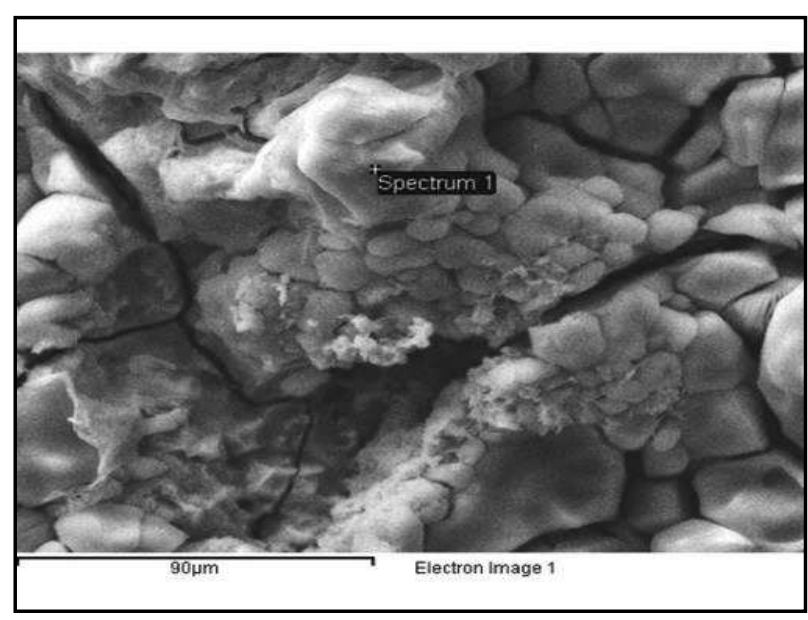

Fig. 26 SEM image for API 5L X65 carbon steel in the 1 $\mathrm{M} \mathrm{H}_{2} \mathrm{SO}_{4}$ taken from one spot of the corrosion product

The sulfur content increases in $1.00 \mathrm{M} \mathrm{H}_{2} \mathrm{SO}_{4}$ because of the higher sulfate concentration. However, the formation of corrosion products consisted mainly of iron oxide $(\mathrm{FeO})$, iron sulfate $\left(\mathrm{FeSO}_{4}\right)$ and iron sulfide $(\mathrm{FeS})$. The high sulfur content might denote a large covered area of $\mathrm{FeSO}_{4}$ film. FeSO4 film pits corrosion, higher sulfide and sulfate ion concentrations and higher pitting levels. Besides, the $\mathrm{O}$ element was also observed in all EDX analyses, and this shows the formation of iron oxide $\left(\mathrm{Fe}_{2} \mathrm{O}_{3}\right)$ compound.

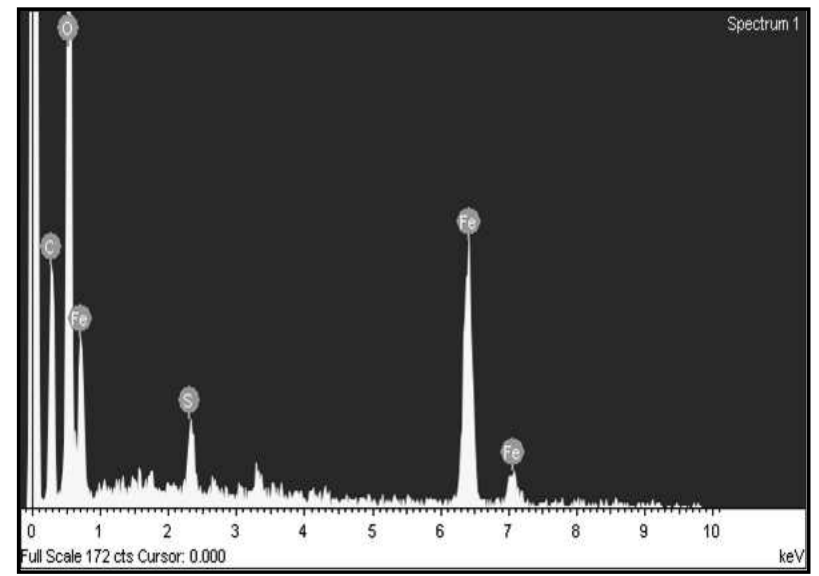

Fig. 27 EDX analysis for API 5L X65 carbon steel in the $1 \mathrm{M} \mathrm{H}_{2} \mathrm{SO}_{4}$ taken from one spot of the corrosion product

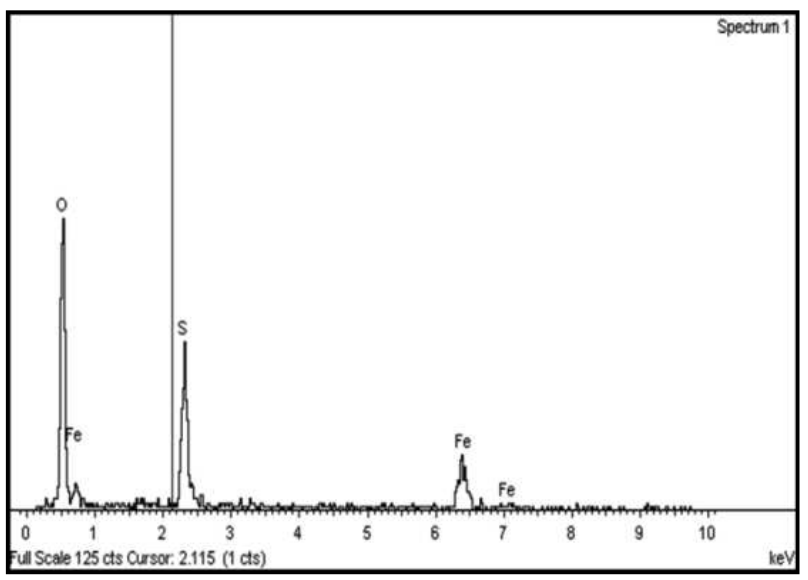

Fig. 28 EDX analysis for API 5L X65 carbon steel in the $1 \mathrm{M} \mathrm{H}_{2} \mathrm{SO}_{4}$ taken from one spot of the corrosion product

Tab. 5 The corrosion's product and composition from EDX analysis

\begin{tabular}{|c|c|c|}
\hline Element & Weight \% & Atomic $\%$ \\
\hline O K & 52.06 & 74.80 \\
\hline S K & 17.92 & 12.85 \\
\hline Fe K & 30.01 & 12.35 \\
\hline Total & 100.00 & 100.00 \\
\hline
\end{tabular}

\section{Conclusions}

The sulfur concentration's confirmation has been carried out using FTIR and AAS spectroscopies in this work. The sulfur concentration in crude oil was estimated using the conversion of sulphate ion concentration by Beer's Law, where the concentration of the 
simulated acidic solution $\mathrm{H}_{2} \mathrm{SO}_{4}$ was determined from this conversion. The corrosion rate determination of API 5L X65 pipeline steel has been carried out using the Tafel extrapolation technique. The corrosion rate of the pipeline steel's internal surface increases with the increasing $\mathrm{H}_{2} \mathrm{SO}_{4}$ concentrations. The highest corrosion rate, the specimen in the $1.00 \mathrm{M} \mathrm{H}_{2} \mathrm{SO}_{4}$, was found to be $4.75 \times 10^{6} \mathrm{mpy}$. The higher the sulfate $\left(\mathrm{SO}_{4}{ }^{2-}\right)$ ion concentration, the more substantial acceleration effect on the corrosion, allowing the pipeline steel's internal surface to be severely corroded. The corrosion products' morphology and confirmation were studied using OM, SEM, and EDX techniques. The corrosion products grown on pipeline steel surfaces in the $\mathrm{H}_{2} \mathrm{SO}_{4}$ solution were mainly composed of iron sulfate $\left(\mathrm{FeSO}_{4}\right)$, iron sulfide $(\mathrm{FeS})$ and iron oxide $(\mathrm{FeO})$. The corrosion mechanism could be linked to the greater tendency of pitting corrosion on the surface.

\section{Acknowledgement}

Authors are very grateful to Universiti Teknikal Malaysia Melaka (UTeM) for the financial and facilities support. Also, special thanks to UTeM for the Zamalah Scheme for PhD support of N.E. Safie.

\section{References}

[1] SENOUCI, A., ELABBASY, M., ELWAKIL, E., ABDRABOU, B., ZAYED, T. (2014). A model for predicting failure of oil pipelines. Structure and Infrastructure Engineering, Vol. 10, No. 3, pp. 375-387. ISSN 1573-2479.

[2] OSSAI, C. I., BOSWELL, B., DAVIES, I. J. (2015). Pipeline failures in corrosive environments-A conceptual analysis of trends and effects. Engineering Failure Analysis, 53, pp. 3658. ISSN 2347-9523.

[3] KUMAR, M. S., SUJATA, M., VENKATASWAMY, M. A., BHAUMIK, S. K. (2008). Failure analysis of a stainless steel pipeline. Engineering Failure Analysis, Vol. 15, No. 5, pp. 497-504. ISSN 1350-6307.

[4] AMANBAYEV, E., ALIMBAYEV, B., MANAPBAYEV, B., DJANUZAKOVA, R. (2019). Internal Propagation Behavior on the Turning Angles in Steel Pipes. Manufacturing Technology, Vol.19, No. 3, pp. 359-365. ISSN 1213-2489.

[5] MERIEM-BENZIANE, M., BOU-SAÏD, B., BOUDOUANI, N. (2017). The effect of crude oil in the pipeline corrosion by the naphthenic acid and the sulfur: A numerical approach. Journal of Petroleum Science and Engineering, 158, pp. 672-679. ISSN 0920-4105.

[6] BRAVO-MÉNDEZ, J., GONZÁLEZVELÁZQUEZ, J. L., DOMÍNGUEZAGUILAR, M. A., RIVAS-LÓPEZ, D. I. (2018). High-temperature corrosion of a UNS K03006 steel pipe in a crude oil vacuum residue distillation unit. Engineering Failure Analysis, 92, pp. 149-162. ISSN 1350-6307.

[7] FAN, Z., HU, X., LIU, J., LI, H., FU, J. (2017). Stress corrosion cracking of L360NS pipeline steel in sulfur environment. Petroleum, Vol. 3, No. 3, pp. 377-383. ISSN 2405-6561.

[8] ASKARI, M., ALIOFKHAZRAEI, M., AFROUKHTEH, S. (2019). A comprehensive review on internal corrosion and cracking of oil and gas pipelines. Journal of Natural Gas Science and Engineering, 71, pp 102971. ISSN: 18755100 .

[9] AZAM, M. A., SUKARTI, S., ZAIMI, M. (2020). Corrosion behavior of API-5L-X42 petroleum/natural gas pipeline steel in South China Sea and Strait of Melaka seawaters. Engineering Failure Analysis, Vol. 115, pp. 104654. ISSN 1350-6307.

[10] NEŠIĆ, S., KAHYARIAN, A., CHOI, Y. S. (2019). Implementation of a comprehensive mechanistic prediction model of mild steel corrosion in multiphase oil and gas pipelines. Corrosion, Vol. 75, No. 3, pp. 274-291. ISSN 0010-9312.

[11] KERMANSHACHI, S., ROUHANIZADEH, B., COBANOGLU, M. M., DAMNJANOVIC, I. (2020). Optimal Pipeline Maintenance Strategies in the United States: Stochastic Reliability Analysis of Gas Pipeline Network Failures. Journal of Pipeline Systems Engineering and Practice, Vol. 11, No. 1, pp. 04019041. ISSN 1949-1190.

[12] DEFTERAIOS, N., KYRANOUDIS, C., NIVOLIANITOU, Z., ANEZIRIS, O. (2020). Hydrogen explosion incident mitigation in steam reforming units through enhanced inspection and forecasting corrosion tools implementation. Journal of Loss Prevention in the Process Industries, Vol. 63, pp. 104016. ISSN 0950-4230.

[13] AZAM, M. A., ABDULLAH, M. F., SHIMODA, T. (2020). Corrosion of weld area at internal surface of pipeline used in oil and gas industry. Journal of Advanced Manufacturing Technology, Vol. 14, No. 2 (2). ISSN 1985-3157. 
[14] ABD, A. A., NAJI, S. Z., HASHIM, A. S. (2019). Failure analysis of carbon dioxide corrosion through wet natural gas gathering pipelines. Engineering Failure Analysis, Vol. 105, pp. 638-646. ISSN 1350-6307.

[15] KADHIM, M. G., ALI, M. T. (2017). A critical review on corrosion and its prevention in the oilfield equipment. Journal of Petroleum Research and Studies, Vol. 7, No. 2, pp. 162-189. ISSN 2220-5381.

[16] NARIMANI, N., ZAREI, B., POURALIAKBAR, H., KHALAJ, G. (2015). Predictions of corrosion current density and potential by using chemical composition and corrosion cell characteristics in microalloyed pipeline steels. Measurement, Vol. 62, pp. 97-107. ISSN 0263-2241.

[17] JASIM, H. H. (2019). Evaluation the Effect of Velocity and Temperature on the Corrosion Rate of Crude Oil Pipeline in the Presence of $\mathrm{CO}_{2} / \mathrm{H}_{2} \mathrm{~S}$ Dissolved Gases. Iraqi Journal of Chemical and Petroleum Engineering, Vol. 20, No. 2, pp. 41-50. ISSN 1997-4884.

[18] SOLOMON, P. R., CARANGELO, R. M. (1982). FTIR analaysis of coal. 1. Techniques and determination of hydroxyl concentrations. Fuel, Vol. 61, No. 7, pp. 663-669. ISSN $0016-$ 2361.

[19] ZHOU, N., WANG, L., THOMPSON, D. W., ZHAO, Y. (2007). Synthesis, electronic, and photophysical properties of cruciform OPE/OPV hybrid oligomer bridged bisfullerene triads. Tetrahedron letters, Vol. 48, No. 20, pp. 3563-3567. ISSN 0040-4039.

[20] WANG, H., DALLA LANA, I. G., CHUANG, K. T. (2002). Kinetics and mechanism of oxidation of hydrogen sulfide by concentrated sulfuric acid. Industrial \& engineering chemistry research, Vol. 41, No. 26, pp. 6656-6662. ISSN 0888-5885.

[21] MORCALI, M. H., KHAJAVI, L. T., AKTAS, S., DREISINGER, D. B. (2019). Oxidative dissolution of nickel matte in dilute sulfuric acid solutions. Hydrometallurgy, 185, pp. 257-265. ISSN 0304-386X.

[22] ABHIJEET, S. B., BALASUBRAMANIAM, R., GUPTA, M. (2008). Corrosion behaviour of $\mathrm{Mg}-\mathrm{Cu}$ and $\mathrm{Mg}-\mathrm{Mo}$ composites in $3.5 \% \mathrm{NaCl}$. Corrosion Science, Vol. 50, No. 9, pp. 2423-2428. ISSN 0010-938X.

[23] ARYA, S. B., BHATTACHARJEE, A., ROY, M. (2018). Electrochemical corrosion behavior of Ti-10V-2Fe-3Al in different corrosive media. Materials and Corrosion, Vol. 69, No. 8, pp. 1025-1038. ISSN 1521-4176.

[24] RASHAD, M., PAN, F., ASIF, M., CHEN, X. (2017). Corrosion behavior of magnesiumgraphene composites in sodium chloride solutions. Journal of magnesium and alloys, Vol. 5, No. 3, pp. 271-276. ISSN: 2213-9567.

[25] AZAM, M. A., IBRAHIM, M. F., ZAIMI, M. (2015). Corrosion analysis of carbon steel pipeline: effect of different sulfuric acid concentrations. Applied Mechanics and Materials, Vol. 699, pp. 215-220. ISSN 1662-7482.

[26] PANOSSIAN, Z., DE ALMEIDA, N. L., DE SOUSA, R. M. F., DE SOUZA PIMENTA, G., MARQUES, L. B. S. (2012). Corrosion of carbon steel pipes and tanks by concentrated sulfuric acid: a review. Corrosion Science, Vol. 58, pp. 1-11. ISSN 0010-938X.

[27] ZHANG, G. A., ZENG, Y., GUO, X. P., JIANG, F., SHI, D. Y., CHEN, Z. Y. (2012). Electrochemical corrosion behavior of carbon steel under dynamic high pressure $\mathrm{H}_{2} \mathrm{~S} / \mathrm{CO}_{2}$ environment. Corrosion Science, Vol. 65, pp. $37-$ 47. ISSN 0010-938X.

[28] PENGHUI, Y., HANGUANG, F., GUOLU, L., JINHAI, L., XUEBO, Z. (2020). Microstructures and properties of carbidic austempered ductile Iron containing $\mathrm{Fe}_{3} \mathrm{C}$ particles and superfine ausferrite. Materials \& $D e-$ sign, Vol. 186, pp. 108363. ISSN 1873-4197.

[29] FATAH, M. C., ISMAIL, M. C., ARIWAHJOEDI, B., KURNIA, K. A. (2011). Effects of sulphide ion on the corrosion behaviour of X52 steel in a carbon dioxide environment at temperature 40 C. Materials Chemistry and Physics, Vol. 127, No. 1-2, pp. 347-352. ISSN 0254-0584.

[30] ABD RASHID, M. W., GAKIM, M., ROSLI, Z. M., AZAM, M. A. (2012). Formation of Cr23C6 during the sensitization of AISI 304 stainless steel and its effect to pitting corrosion. International Journal of Electrochemical Science, Vol. 7, pp. 9465-9477. ISSN 1452-3981.

[31] KUSMIC, D., VAN, D. T., HRUBY, V. (2018). Corrosion and Wear Resistance of Plasma Nitrided and Duplex Treated 42CrMo4 Steel. $\mathrm{Ma}$ nufacturing Technology, Vol.18, No. 2, pp. 259265. ISSN 1213-2489.

[32] CALEYO, F., VELÁZQUEZ, J. C., VALOR, A., HALLEN, J. M. (2009). Probability distribution of pitting corrosion depth and rate in underground pipelines: A Monte Carlo study. 
Corrosion Science, Vol. 51, No. 9, pp. 1925-1934. ISSN 0010-938X.

[33] YU, H. X., XU, X. L., AND YU, Z. W. (2019). Pitting-corrosion on internal wall of tee-pipe joined with main-pipe for seawater tank-washing system of a tanker. Engineering Failure Analysis, Vol. 104, pp. 439-447. ISSN 1350-6307.

[34] AHAMMED, M., MELCHERS, R. E. (1995). Probabilistic analysis of pipelines subjected to pitting corrosion leaks. Engineering Structures, Vol. 17, No. 2, pp. 74-80. ISSN 0141-0296.

[35] MORALES-GIL, P., NEGRÓN-SILVA, G., ROMERO-ROMO, M., ÁNGELESCHÁVEZ, C., PALOMAR-PARDAVÉ, M.
(2004). Corrosion inhibition of pipeline steel grade API 5L X52 immersed in a $1 \mathrm{M} \mathrm{H}_{2} \mathrm{SO}_{4}$ aqueous solution using heterocyclic organic molecules. Electrochimica acta, Vol. 49, No. 26, pp. 4733-4741. ISSN 0013-4686.

[36] KHAN, S. M., SEIKH, A. H., BAIG, M., EL RAYES, M. M. (2015). Electrochemical Corrosion Behavior of Spirally-welded API X-70 Line-pipe Steel in Acidic and Salt Media, Manufacturing Science and Technology, Vol. 3, No. 5, pp. 286-293. ISSN 2333-2697.

[37] ELLISON, B. T., SCHMEAL, W. R. (1978). Corrosion of steel in concentrated sulfuric acid. Journal of the electrochemical society, Vol. 125, No. 4, pp. 524. ISSN 0013-4651. 